\title{
On the Investment Sensitivity of Debt UNDER UNCERTAINTY
}

\author{
Christopher F Baum* \\ Department of Economics, Boston College and DIW Berlin \\ Mustafa Caglayan \\ Department of Economics, University of Sheffield \\ Oleksandr Talavera \\ School of Economics, University of East Anglia
}

October 3, 2009

\begin{abstract}
We investigate the impact of debt on a panel of U.S. manufacturing firms' capital investment behavior as the underlying firm-specific and market-level uncertainty changes. Our estimates show that the influence of leverage on capital investment may be stimulating or mitigating depending on the effects of uncertainty.
\end{abstract}

Keywords: capital investment, leverage, uncertainty

JEL: E22, G31, D81

\footnotetext{
${ }^{*}$ Christopher F Baum and Oleksandr Talavera gratefully acknowledge financial support from the Fritz Thyssen Foundation. Corresponding author: Christopher F Baum, Department of Economics, Boston College, Chestnut Hill, MA 02467 USA, Tel: 617-552-3673, fax 617-552-2308, e-mail: baum@bc.edu.
} 


\section{Introduction}

Researchers have expended considerable effort in trying to understand the effects of capital structure on the investment behavior of a firm. It is well understood that preexisting debt may discourage or distort firms' capital investment activities, for part of the increase in firm value from new investment projects will accrue to existing debtholders. ${ }^{1}$ Contrarily, it is also possible that preexisting debt could induce excessive risk-taking when growth options are prematurely exercised. ${ }^{2}$

In this paper, we empirically examine the role of leverage on U.S. manufacturing firms' investment behavior while incorporating the effects of firmspecific and market-level uncertainty in that relationship on their own and in conjunction with leverage. Our empirical model is motivated by Bo and Sterken (2002) who provide an analytical model to bring in debt and (interest rate) uncertainty on their own and in interaction to explain firms' capital investment behavior. Their model is based on Nickell (1978) and assumes that managers seek to maximize expected cash flow while minimizing its volatility. Our results reveal that leverage may have a positive or negative impact on firms' investment as uncertainty changes. ${ }^{3}$ Differing from their approach, we also control for firms' cash flow in our empirical investigation. We derive a proxy for intrinsic (firm specific) uncertainty from firms' stock returns and another proxy for market (macro) uncertainty from S\&P 500

\footnotetext{
${ }^{1}$ See, for example, Myers (1977), Lang, Ofek and Stulz (1996), Hennessy (2004).

${ }^{2}$ See including Jensen and Meckling (1976) and Sundaresan and Wang (2006).

${ }^{3}$ Also see Bloom, Bond and Van Reenen (2007) who show that investment will respond more cautiously to a given demand shock at higher levels of uncertainty and Baum, Caglayan and Talavera (in press) who provide evidence that, depending on the type of uncertainty, investment may be stimulated or curtailed as a firm's cash flow varies.
} 
index returns. ${ }^{4}$

\section{Empirical findings}

\subsection{Data sources and construction}

In our empirical analysis, we employ an unbalanced panel of manufacturing firms for the 1988-2005 period drawn from Standard and Poor's Industrial Annual COMPUSTAT database. Our sample contains 7,769 firm-years for which the replacement value of the real capital stock may be imputed by the method of Salinger and Summers (1983). We only consider firms who have not undergone substantial changes in their composition during the sample period. As these changes are not directly observable, we calculate the growth rate of each firm's real total assets, and trim the annual distribution of this growth rate by the 1st and 99th percentiles. Values of the investment-tocapital, cash flow/total assets, debt/total assets ratios and Tobin's $Q$ outside the 1-99th percentile range are judged implausible. One per cent from either end of the annual returns distribution was trimmed. Our estimation sample, taking lagged values and missing values into account, contains 6,514 firmyears pertaining to 481 firms. ${ }^{5}$

Using a method proposed by Merton (1980), we compute firm- and market-specific uncertainty measures utilizing the intra-annual variations in stock returns and aggregate financial market series. This approach avoids such potential problems as high shock persistence when moving average rep-

\footnotetext{
${ }^{4}$ Baum, Caglayan and Talavera (2008) show that the impact of market, firm-specific and CAPM-based uncertainty on firms' investment can differ in sign and magnitude.

${ }^{5}$ Our investigation yields similar results when we trimmed the top and bottom $5 \%$ of the sample.
} 
resentations are used, and low correlation in volatility when $\mathrm{ARCH} / \mathrm{GARCH}$ models are applied to quantify volatility in low-frequency series. ${ }^{6}$

\section{$2.2 \quad$ Descriptive statistics}

Descriptive statistics for the firm-year observations entering the analysis, including those observations used to define lagged values, are presented in Table 1. The average (median) investment rate (defined as the ratio of real investment expenditures to the lagged replacement value of the real capital stock) for our sample is about $11 \%$ (8.3\%) and that of Tobin's $Q$ is about 2.95 (1.71). These values of $Q$ are comparable to those in Table 1 of Leahy and Whited (1996). The last two lines, labeled as $\eta_{i t}$ and $\varepsilon_{t}$, give descriptive statistics for the constructed measures of uncertainty obtained from firm stock returns and S\&P index returns, respectively. ${ }^{7}$

\subsection{The linkages between uncertainty, leverage and capital investment}

We employ the dynamic panel data (DPD) approach developed by Arellano and Bond (1991). All models are estimated using the two-step System GMM estimator of Blundell and Bond (1998).

Column 1 of Table 2 presents a standard investment model which includes the basic explanatory variables including the lagged dependent variable, $Q, C F / T A$, and lagged $m v B / T A$ (leverage), where we deflate the

\footnotetext{
${ }^{6}$ The Merton approach differs from that of Bloom et al. (2007), who also make use of daily stock returns data, but agrees in spirit in taking the daily variations into account. See Baum, Caglayan and Ozkan (2004) for a detailed discussion of the Merton procedure.

${ }^{7}$ In the estimated model, these measures enter in lagged form to reflect the manager's information set at time $t$.
} 
cash flow $(C F)$ and the market value of the debt $(m v B)$ by beginning-ofperiod total assets $(T A)$. Results from this benchmark model are similar to those reported in the literature with positive and significant coefficients on the lagged investment rate, $Q$ and $C F / T A$. The coefficient of leverage is not significantly different from zero. The $J$ statistic (and the corresponding $p$-value) is the Hansen-Sargan test statistic, indicating that the test for overidentifying restrictions is satisfactory (as it is in all reported estimates). Furthermore, we reject the presence of second-order autocorrelation $(A R(2))$ validating the use of suitably lagged endogenous variables as instruments. ${ }^{8}$

Given satisfactory benchmark results, we augment our basic model with the lagged value of intrinsic uncertainty $\left(\eta_{i t}\right)$. The results in column 2 show that the coefficient of the intrinsic uncertainty measure cannot be distinguished from zero. Once again, leverage does not enter the equation as a significant explanatory factor. We then include market uncertainty, $\varepsilon_{t}$, in Column 3. While the coefficients of the lagged investment rate, cash flow rate and Tobin's $Q$ are significant with the correct signs, that of leverage cannot be distinguished from zero. Market uncertainty enters with a significant negative coefficient. In Column 4, we include both types of uncertainty in the equation, and find that intrinsic uncertainty is still insignificant while the coefficient of extrinsic uncertainty is negative and significant.

Leverage fails to play an important role in any of the estimated equations of Table 2. However, we have only considered leverage in isolation, not in conjunction with uncertainty terms. In Table 3, we present estimates in

\footnotetext{
${ }^{8}$ The second through fourth lags of the investment rate, Tobin's $Q$, the Cash flow ratio and the leverage are employed as GMM instruments. In the models including lagged uncertainty measures, second through fourth lags of those measures were also included as GMM instruments.
} 
which interaction terms are added. In Column 1, neither the leverage term nor the interaction term with intrinsic uncertainty is significantly different from zero. In contrast to the earlier results, the model of Column 1 shows that intrinsic uncertainty has a negative and significant effect on investment. In Column 2, where an interaction with extrinsic uncertainty is included, both leverage and the interaction term have significant effects with positive and negative coefficients, respectively. Column 3 includes both sets of interaction terms, and shows that both forms of uncertainty as well as their interactions with firm leverage are significant. The main effect of leverage is not precisely estimated.

To evaluate the overall impact of leverage on firm investment we must simultaneously consider the main effect and interaction effects. These derivatives, graphed in Figure 1 for selected percentiles of each uncertainty measure, are interesting and intuitive. The precise nature of the impact of leverage when intrinsic uncertainty varies is illustrated in Figure 1, Panel A, for $\partial(I / K) / \partial($ Leverage $)$ when we allow intrinsic uncertainty to change while extrinsic (market) uncertainty is set to its median level. Here, we see that the impact of leverage on investment is negative for percentiles $p 5, p 10, p 25, p 50$, followed by positive effects for percentiles $p 75, p 90, p 95$. We can explain this observation by managers' willingness to take excessive risks at the expense of the existing debtholders when firm-specific uncertainty increases.

Panel B shows that the impact of leverage on investment when market uncertainty changes. This relationship is the opposite of the previous case in Panel A. The values obtained for the same derivative when we allow market uncertainty to increase show that leverage plays a stimulative role in investment at lower levels of market uncertainty. Once market uncertainty 
crosses a certain threshold (here, near the $25^{\text {th }}$ percentile of its sample values), leverage will curtail investment. This interpretation is reasonable, for managers could generally tap existing credit lines to expand their business in times of low to moderate levels of market uncertainty. As market turmoil increases, banks will curtail credit lines rendering any new investment unrealistic regardless of the potential returns from lending.

\section{Conclusions}

In this paper we show that the overall effect of leverage on capital investment may be stimulating or mitigating depending on the underlying uncertainty. In contrast to Bloom et al. (2007) who find that firm-specific time varying uncertainty affects firms' behavior while macroeconomic uncertainty does not, our findings suggest that both firm-specific and market-level (macroeconomic) uncertainty can enhance or impair fixed investment, alone or in conjunction with firms' degree of leverage, clouding the relationship between investment and uncertainty (Boyle and Guthrie (2003)). 


\section{References}

Arellano, M. and Bond, S. (1991), 'Some tests of specification for panel data: Monte Carlo evidence and an application to employment equations', Review of Economic Studies 58(2), 277-97.

Baum, C. F., Caglayan, M. and Ozkan, N. (2004), 'Nonlinear effects of exchange rate volatility on the volume of bilateral exports', Journal of Applied Econometrics 19, 1-23.

Baum, C. F., Caglayan, M. and Talavera, O. (2008), 'Uncertainty determinants of firm investment', Economics Letters 98(3), 282-287.

Baum, C. F., Caglayan, M. and Talavera, O. (in press), 'On the sensitivity of firms' investment to cash flow and uncertainty', Oxford Economics Papers .

Bloom, N., Bond, S. and Van Reenen, J. (2007), 'Uncertainty and investment dynamics', Review of Economic Studies 74(2), 391-415.

Blundell, R. and Bond, S. (1998), 'Initial conditions and moment restrictions in dynamic panel data models', Journal of Econometrics 87, 115-143.

Bo, H. and Sterken, E. (2002), 'Volatility of the interest rate, debt and firm investment: Dutch evidence', Journal of Corporate Finance 8(2), 179193.

Boyle, G. W. and Guthrie, G. A. (2003), 'Investment, uncertainty, and liquidity', The Journal of Finance 58(5), 2143-2166.

Hennessy, C. A. (2004), 'Tobin's Q, debt overhang and investment', Journal of Finance 59, 1717-1742.

Jensen, M. C. and Meckling, W. H. (1976), 'Theory of the firm: Managerial behavior, agency costs and ownership structure', Journal of Financial Economics 3(4), 305-360.

Lang, L., Ofek, E. and Stulz, R. M. (1996), 'Leverage, investment, and firm growth', Journal of Financial Economics 40(1), 3-29.

Leahy, J. V. and Whited, T. M. (1996), 'The effect of uncertainty on investment: Some stylized facts', Journal of Money, Credit and Banking 28(1), 64-83.

Merton, R. C. (1980), 'On estimating the expected return on the market: An exploratory investigation', Journal of Financial Economics 8, 323-61.

Myers, S. C. (1977), 'Determinants of corporate borrowing', Journal of Financial Economics 25, 25-43. 
Nickell, S. J. (1978), The investment decision of firms, Cambridge University Press, Cambridge, UK.

Salinger, M. and Summers, L. (1983), Tax reform and corporate investment: A microeconomic simulation study, in M. Feldstein, ed., 'Behavioral Simulation Models in Tax Policy Analysis', University of Chicago Press.

Sundaresan, S. and Wang, N. (2006), Dynamic investment, capital structure, Working paper, Columbia University. 
Table 1: Descriptive statistics, 1987-2005

\begin{tabular}{lrrrrr}
\hline \hline & $p 25$ & $p 50$ & $p 75$ & mean & $s d$ \\
\hline Investment rate & 0.0509 & 0.0851 & 0.1369 & 0.1221 & 0.1473 \\
Tobin's Q & 0.8879 & 1.7323 & 3.3733 & 3.1745 & 4.9136 \\
$C F / T A$ & 0.0768 & 0.1135 & 0.1532 & 0.1170 & 0.0662 \\
$m v B / T A$ & 0.1520 & 0.2502 & 0.3530 & 0.2664 & 0.1616 \\
$\eta_{i t}$ & 0.4665 & 0.7246 & 1.1321 & 0.8813 & 0.6019 \\
$\varepsilon_{t}$ & 0.0875 & 0.1842 & 0.2953 & 0.2130 & 0.1431 \\
Firm-years & 7,769 & & & & \\
Firms & 500 & & & & \\
\hline \hline
\end{tabular}

Notes: $p 25, p 50, p 75$ are the quartiles of the variables, while $s d$ are their standard deviations. The investment rate is the ratio of real investment to the lagged value of the real capital stock, $K_{t-1}$. The $\eta_{i t}$ term is a measure of intrinsic uncertainty, while $\varepsilon_{t}$ refers to extrinsic (market) uncertainty. 
Table 2: Robust GMM estimates of the investment rate

\begin{tabular}{lrrrr} 
& $(1)$ & $(2)$ & $(3)$ & $(4)$ \\
\hline Investment rate $t-1$ & $0.392^{* * *}$ & $0.418^{* * *}$ & $0.414^{* * *}$ & $0.387^{* * *}$ \\
Tobin's $Q$ & $(0.053)$ & $(0.053)$ & $(0.052)$ & $(0.056)$ \\
& $0.006^{* * *}$ & $0.006^{* * *}$ & $0.007^{* * *}$ & $0.005^{* * *}$ \\
$C F / T A$ & $(0.001)$ & $(0.001)$ & $(0.001)$ & $(0.002)$ \\
& $0.298^{* * *}$ & $0.265^{* * *}$ & $0.230^{* * *}$ & $0.269^{* * *}$ \\
$m v B / T A$ & $(0.078)$ & $(0.080)$ & $(0.077)$ & $(0.078)$ \\
& 0.007 & 0.015 & 0.035 & 0.003 \\
$\eta_{i, t-1}$ & $(0.038)$ & $(0.035)$ & $(0.035)$ & $(0.041)$ \\
& & 0.003 & & -0.002 \\
$\varepsilon_{t-1}$ & & $(0.004)$ & & $(0.007)$ \\
& & & $-0.033^{* * *}$ & $-0.024^{* *}$ \\
Constant & & & $(0.008)$ & $(0.012)$ \\
& 0.010 & 0.005 & 0.014 & 0.024 \\
\hline Firm-years & $(0.019)$ & $(0.017)$ & $(0.017)$ & $(0.020)$ \\
Firms & 6,514 & 6,514 & 6,514 & 6,514 \\
$J$ & 481 & 481 & 481 & 481 \\
$J$ pvalue & 462.542 & 470.923 & 473.053 & 448.855 \\
AR(2) & 0.458 & 0.557 & 0.530 & 0.121 \\
AR(2) pvalue & -0.543 & -0.410 & -0.406 & -0.586 \\
\hline \multicolumn{2}{c}{ Notes: $* * p<0.587$} & 0.682 & 0.684 & 0.558 \\
\hline & & & \\
& & & &
\end{tabular}


Table 3: Robust GMM estimates of the investment rate

\begin{tabular}{|c|c|c|c|}
\hline & (1) & (2) & (3) \\
\hline${\text { Investment } \text { rate }_{t-1}}$ & $\begin{array}{r}0.326^{* * *} \\
(0.058)\end{array}$ & $\begin{array}{r}0.484^{* * *} \\
(0.072)\end{array}$ & $\begin{array}{r}0.353^{* * *} \\
(0.051)\end{array}$ \\
\hline Tobin's $Q$ & $\begin{array}{r}0.008^{* * *} \\
(0.003)\end{array}$ & $\begin{array}{r}0.002 \\
(0.004)\end{array}$ & $\begin{array}{r}0.007^{* *} \\
(0.003)\end{array}$ \\
\hline$C F / T A$ & $\begin{array}{r}0.332^{* * *} \\
(0.083)\end{array}$ & $\begin{array}{r}0.577^{* * *} \\
(0.113)\end{array}$ & $\begin{array}{r}0.326^{* * *} \\
(0.076)\end{array}$ \\
\hline$m v B / T A$ & $\begin{array}{r}0.002 \\
(0.023)\end{array}$ & $\begin{array}{r}0.103^{* * *} \\
(0.028)\end{array}$ & $\begin{array}{r}-0.013 \\
(0.021)\end{array}$ \\
\hline$\eta_{i, t-1}$ & $\begin{array}{r}-0.026^{* * *} \\
(0.009)\end{array}$ & & $\begin{array}{r}-0.045^{* * *} \\
(0.014)\end{array}$ \\
\hline$(m v B / T A) \times \eta_{i, t-1}$ & $\begin{array}{r}0.032 \\
(0.022)\end{array}$ & & $\begin{array}{r}0.108^{* * *} \\
(0.036)\end{array}$ \\
\hline$\varepsilon_{t-1}$ & & $\begin{array}{r}0.111^{* * *} \\
(0.039)\end{array}$ & $\begin{array}{r}0.100^{* * *} \\
(0.033)\end{array}$ \\
\hline$(m v B / T A) \times \varepsilon_{t-1}$ & & $\begin{array}{r}-0.485^{* * *} \\
(0.133)\end{array}$ & $\begin{array}{r}-0.382^{* * *} \\
(0.111)\end{array}$ \\
\hline Constant & $\begin{array}{c}0.024^{*} \\
(0.014)\end{array}$ & $\begin{array}{r}-0.043^{* *} \\
(0.018)\end{array}$ & $\begin{array}{r}0.028^{* *} \\
(0.013)\end{array}$ \\
\hline Firm-years & 6,514 & 6,514 & 6,514 \\
\hline Firms & 481 & 481 & 481 \\
\hline$J$ & 427.232 & 88.116 & 439.902 \\
\hline$J$ pvalue & 0.167 & 0.143 & 0.201 \\
\hline $\operatorname{AR}(2)$ & -0.762 & -0.239 & -0.651 \\
\hline $\operatorname{AR}(2)$ pvalue & 0.446 & 0.811 & 0.515 \\
\hline
\end{tabular}


Figure 1. Sensitivity of investment to leverage
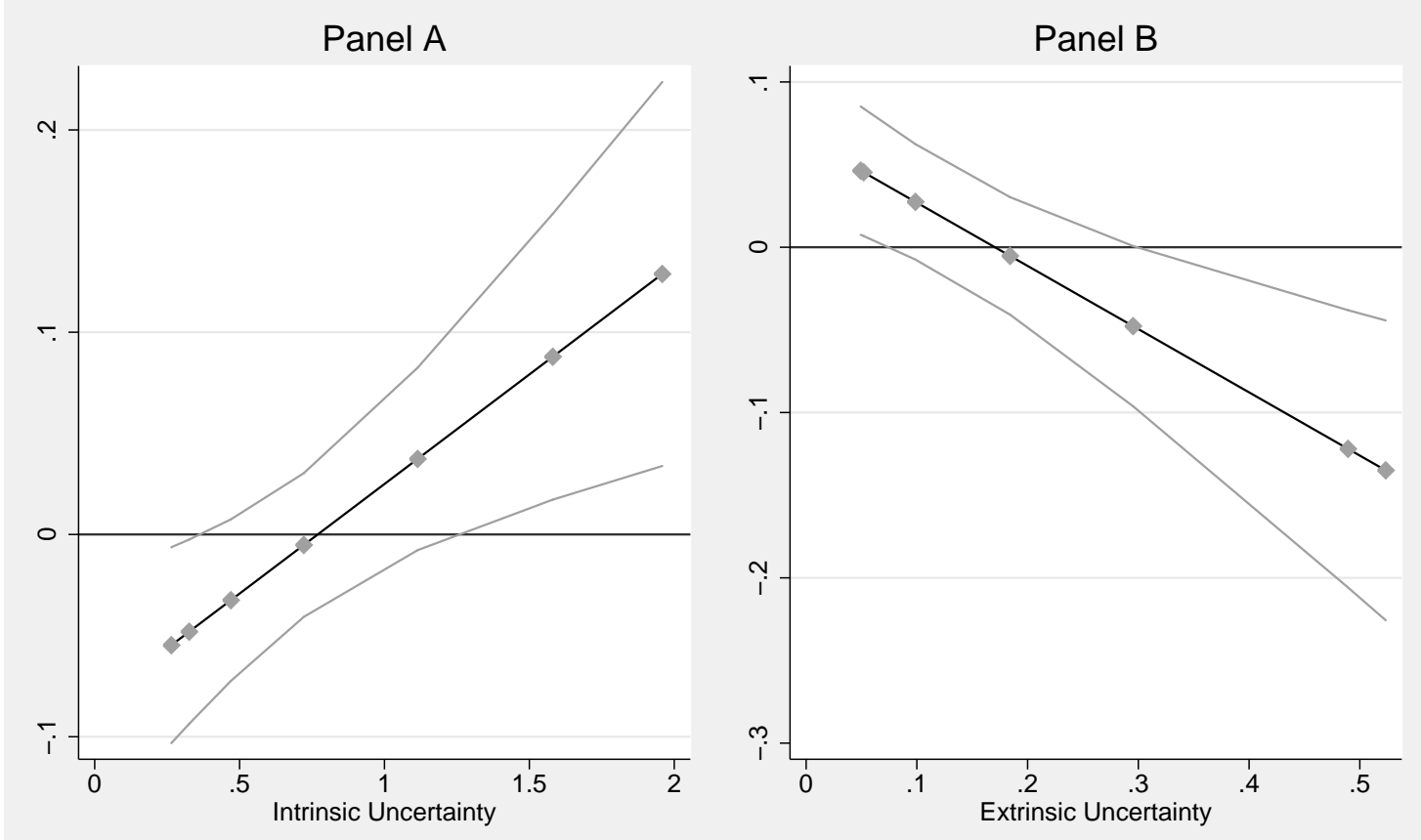